This article is a non-reviewed preprint published at EarthArXiv.

\title{
1 Submarine channels "swept" downstream after bend cutoff in salt 2 basins
}

3

4 Jacob A. Covault, Zoltán Sylvester, Michael R. Hudec, Can Ceyhan, and Dallas Dunlap

7 Corresponding author email: jake.covault@beg.utexas.edu

9 ABSTRACT aggradation and incision, set the stratigraphic architecture of channelized depositional systems.

12 Early work on submarine-channel evolution has suggested that downstream translation is rare. We propose that downstream translation of bends might be common in deep-water salt-tectonic

14 provinces, where complex topography can localize channel pathways that promote meander

Channel-bend expansion and downstream translation, as well as vertical movements by cutoffs and the generation of high-curvature bends. We use three-dimensional seismic-reflection data from a region with salt-influenced topography in the Campos basin, offshore Brazil, to characterize the structural geometry of a salt diapir and stratigraphic architecture of an adjacent $\sim 18 \mathrm{~km}$-long reach of a submarine-channel system. We interpret the structural and stratigraphic evolution, including meander-cutoff development near the salt diapir followed by $\sim 10 \mathrm{~km}$ of downstream translation of a channel bend. We test the stratigraphic evolution with a simple numerical model of channel meandering. This integrated subsurface characterization and stratigraphic modeling study sheds light on the processes and controls of submarine-channel downstream translation, which might be common in rapidly deforming settings, such as salt basins, that promote localized subsidence, meander cutoffs, and rapidly translating, high-curvature bends. 
INTRODUCTION

Submarine channels are conduits for sediment-gravity flows to deep water (Piper and

28 Normark, 2001), delivering sediment to the largest detrital accumulations on Earth in submarine

29 fans (Barnes and Normark, 1985). Submarine-channel deposits contain a record of deep-water 30 sediment dispersal (Hubbard et al., 2014) and changes in upstream source areas (Romans et al., 31 2016) as well as form hydrocarbon reservoirs (Pettingill and Weimer, 2002) and store large 32 amounts of organic carbon (Galy et al., 2008). Submarine channels have been known since the 331980 's to exhibit planform morphologic characteristics similar to rivers (e.g., Damuth et al., 1983);

34 however, some of the influential papers have stressed their unique migration style compared to 35 their fluvial counterparts (e.g., Peakall et al., 2000; Wynn et al., 2007). This is important because 36 channel migration, that is, the expansion and downstream translation of bends (i.e., "swing" and 37 "sweep"; Posamentier, 2003), as well as vertical movements by aggradation and incision, set the 38 stratigraphic architecture of channelized depositional systems (Sylvester et al., 2011; Jobe et al., 39 2016). For example, combined translation and expansion of river bends, with little aggradation, 40 are thought to produce sheet-like sand bodies, whereas limited translation and significant 41 aggradation of submarine-channel bends result in stacks of ribbon-like sand bodies (Peakall et al., 42 2000). Early work on submarine-channel evolution has suggested that downstream translation is 43 rare or nonexistent (e.g., Peakall et al., 2000). However, downstream translation has been observed 44 since then in three-dimensional (3D) seismic-reflection datasets and sometimes attributed to 45 allogenic changes in sediment delivery to the system (e.g., Posamentier, 2003; Posamentier and 46 Kolla, 2003; Kolla et al., 2012; Janocko et al., 2013). Although channel migration is often 
47 discussed in terms of expansion, translation, and rotation, a clear understanding of when and why

48 channel bends expand or translate is still lacking. This is especially true for submarine channels.

Based on insights from rivers (Howard and Knutson, 1984; Smith et al., 2009; Ghinassi et

50 al., 2016), we propose that downstream translation of bends might be common in settings that

51 promote the generation of high-curvature bends, either as a result of cutoffs or other perturbations

52 to the equilibrium plan-view channel pattern. Such settings include deep-water salt-tectonic

53 provinces (Hudec and Jackson, 2007), in which rapid rates of deformation commonly create

54 complex topography that localizes channel pathways and depocenters (e.g., Gee and Gawthorpe,

55 2008). Channel-sculpting sediment-gravity flows tend to follow the direction of steepest descent

56 across a slope, and salt deformation can create topography that draws gravity flows away from the

57 regional slope of a continental margin. The resulting sediment-dispersal system might contain complex and surprising channelized stratigraphic patterns, such as anomalous meander-loop

59 geometries (e.g., Mendoza-Veloza, 2007). Notably, these stratigraphic patterns are a result of

60

61

62

63

64 tectonic deformation and gravity-flow interactions with the resultant topography, independent of any major changes in sediment delivery to the submarine-channel system.

Here, we use 3D seismic-reflection data from the Campos basin, offshore Brazil, to characterize the structural geometry of a salt diapir and stratigraphic architecture of a $\sim 18 \mathrm{~km}$-long reach of a submarine-channel system (Figs. 1,2). We interpret the structural and stratigraphic evolution, including meander-cutoff development adjacent to a salt diapir followed by $\sim 10 \mathrm{~km}$ of downstream translation of a channel bend. We test the stratigraphic evolution with a simple numerical model that we have developed based on the Howard and Knutson (1984) meanderingchannel model (Sylvester and Covault, 2016). Our goal with this subsurface characterization and stratigraphic modeling study is to shed light on the processes and controls of submarine-channel 
70 downstream translation, which might be common in rapidly deforming settings, like salt basins,

71 that promote localized subsidence, meander cutoffs, and rapidly translating, high-curvature bends.

72

\section{GEOLOGIC SETTING}

The Campos basin is located in water depths $>200 \mathrm{~m}$ along the southeastern continental margin of Brazil in the South Atlantic Ocean (Carminatti and Scarton, 1991; Bruhn et al., 2003) (Fig. 1). It is separated from the adjacent Espirito Santo (to the north) and Santos (to the south) basins by northwest-southeast-oriented basement highs (Guardado et al., 2000). The Campos basin is one of the most productive hydrocarbon-bearing basins in the world (Mohriak et al., 1990); in 2017, total daily production was 1.3 million barrels of oil and 25 million cubic meters of natural gas from a variety of reservoirs, including Cretaceous to Miocene siliciclastic turbidites (Mohriak et al., 1990; Bruhn et al., 2003).

The Campos basin initiated during Late Jurassic breakup of Gondwana and opening of the South Atlantic Ocean (Guardado et al., 1990). The basin fill comprises Berriasian-early Aptian continental rift deposits, overlain by middle Aptian salt, an early-middle Albian carbonate platform, and a late Albian to present succession of progressively deeper-water continental-margin deposits (Bruhn, 1998). The Cretaceous-present paleoflow direction is generally northwest-tosoutheast because of the regional slope of the Brazilian continental margin (Fig. 1). However, paleoflow direction in the Campos basin varies depending on local structural configuration and orientation of topographic lows; in an MS thesis at the University of Texas at Austin, Ceyhan (2017) interpreted northwest-to-southeast, west-to-east, and north-to-south paleoflow for Pliocene-Pleistocene channel systems. 
The Aptian salt plays an important role in establishing the structural style of the Campos

93 basin. The base of the Aptian is a detachment surface (Fetter, 2009). Below the detachment, the

main structural features are horsts and grabens bounded by steep normal faults active during Early Cretaceous rifting (Chang et al., 1992). Above the detachment, salt deformation was initiated by early Albian eastward basin tilting (De Gasperi and Catuneanu, 2014). Salt deformation has resulted in structural domains including a proximal domain of east-to-west extension and extensional diapirs, an extensional to compressional intermediate, transitional domain of west-toeast translation and shortened diapirs, and a distal domain of west-to-east contraction within a foldand-thrust belt (Demercian et al., 1993; Mohriak et al., 2012). We focused on the seismic stratigraphy of a Miocene submarine-channel system in the intermediate structural domain of the Campos basin (Fig. 1).

\section{DATA AND METHODS}

\section{Subsurface data and interpretation}

We used amplitude and coherence (i.e., similarity between adjacent seismic traces; Bahorich and Farmer, 1995) attributes generated from a Kirchhoff pre-stack depth-migrated 3D seismic-reflection volume with wavelengths at the depths of interest of $\sim 20-50 \mathrm{~m}$ (vertical resolution $\sim 5-12.5 \mathrm{~m}$ ) and $25 \mathrm{~m}$ horizontal sampling rate. The seismic-reflection volume was donated by Investigação Petrolífera Limitada (PGS). Seismic-reflection data were processed to zero phase. We used the Paradigm ${ }^{\circledR}$ SeisEarth $₫$ interpretation and visualization product suite to map six regional horizons based on line-by-line continuity and terminations of relatively highamplitude seismic reflections (Figs. 2, 3). We used root mean square (RMS) amplitude maps to highlight channel systems to interpret in more detail (cf. De Ruig and Hubbard, 2006) (Fig. 4). We 
115 also interpreted a series of discontinuous, high-amplitude seismic reflections defining channelized 116 deposits by selecting a reflection and using a 3D propagator algorithm to cross-correlate nearest-

117 neighbor seismic traces to within a defined confidence interval (Fig. 5) (cf. Madof et al., 2009).

118 Horizons 1 and 6 are interpreted to be base and top, respectively, of the Miocene based on Ceyhan 119 (2017) and published seismic-stratigraphic studies and stratigraphic charts (Winter et al., 2007; 120 Fetter, 2009; Contreras et al., 2010; Contreras, 2011).

122 profile A of Figure 3. For the restored sections, we assumed a regional topographic slope of $0.18^{\circ}$, 123 which is parallel to the modern slope in the study area. We interpreted deflections to this regional 124 slope based on the positions of channel systems, which we assumed to follow topographic lows. 125 We restored all bedding to the topographic surface using flexural slip because we interpreted that 126 salt diapir uplift was a result of regional shortening (see below). We did not decompact sediment 127 because our primary concern in the restorations was the evolution of surface topography. 128 Therefore, unit thicknesses are incorrect, but we have captured the interplay between salt 129 deformation and topography.

\section{Numerical model of channel evolution}

We employ a simple kinematic meandering model that is based on Howard and Knutson 133 (1984), using a formulation that is equivalent to the approach of Ikeda et al. (1981) (Sun et al., 134 1996), to better understand the migration patterns of submarine channels (i.e., expansion and 135 translation). A key aspect of this model is that migration rate is a function of the weighted sum of 136 upstream curvatures. To compute the migration rate, the upstream curvatures are converted to a 137 "nominal" migration rate, defined as follows: 


$$
R_{0}=\frac{k_{l} W}{R}(1)
$$

where $R_{0}$ is the nominal migration rate, $k_{l}$ is a migration rate constant, $W$ is channel width, and $R$ is radius of curvature. Then, the actual migration rate $R_{1}$ can be estimated using:

$$
R_{1}(s)=\Omega R_{0}(s)+\left(\Gamma \int_{0}^{\infty} R_{0}(s-\xi) G(\xi) d \xi\right)\left(\int_{0}^{\infty} G(\xi) d \xi\right)^{-1}
$$

where $\Omega$ and $\Gamma$ are weighting parameters with values of -1 and 2.5 , and $G(\xi)$ is an exponential weighting function:

$$
G(\xi)=e^{-\alpha \xi}
$$

The weighting decreases exponentially with distance $\xi$ from the point of interest and the exponent $\alpha$ is a function of channel depth $D$ and the friction factor $C_{f}$,

$$
\alpha=2 k \frac{C_{f}}{D}(4)
$$

where $k$ is a constant that takes the value of 1.0 (Howard and Knutson, 1984). In the original formulation of the model, in an attempt to mimic the observations of Hickin and Nanson (1975), curvatures higher than a critical value result in a lower migration rate (Howard and Knutson, 1984). However, new data from modern rivers suggest that migration rate increases with higher curvatures (Furbish, 1988; Sylvester et al., in revision); therefore, for all curvature values, we use a simple linear relationship between curvature and nominal migration rate (Eq. 1).

The Howard and Knutson (1984) model has been previously used in modeling subaerial and submarine meander development (e.g., Finnegan and Dietrich, 2011; Limaye and Lamb, 2014; Sylvester and Covault, 2016). While the model we are using only captures the large-scale kinematics of meandering and does not reproduce phenomena like compound meander development and upstream influence of curvature, it captures well the translation and expansion of meander bends and it provides a simple framework with a small number of parameters to explore the origins of the unusual bends observed in the Campos basin. 


\section{RESULTS}

163

164

165 166

167 168 169

\section{Subsurface characterization}

We mapped six horizons across a $\sim 12 \times 18 \mathrm{~km}$ area of the intermediate, transitional structural domain of the Campos basin, in water depths between $2100-2500 \mathrm{~m}$ (Fig. 1). We will describe the seismic character from the base of the subsurface section (horizon 1) to the top (horizon 6) (Figs. 2, 3). We did not interpret the detailed seismic-stratigraphic architecture between horizons 1 and 3; we mapped these horizons for the purposes of the structural restoration presented below (Fig. 7).

Horizon 1 is the base of a section of seismic reflections including a high-amplitude package confined within large-scale concave-up surfaces defined by reflection terminations (Figs 2, 3). Reflections are more continuous and lower amplitude outside of the concave-up surfaces (Fig. 3). An RMS-amplitude extraction between horizons 1 and 2 shows a north-south-oriented channel pattern, which is continuous across a salt diapir (Fig. 4A). Seismic reflections are truncated against the western side of the diapir (Fig. 3). We interpret that the package of high-amplitude seismic reflections between horizons 1 and 2 represents channel deposits. The trend of the channel system is oriented directly over the salt diapir (Fig. 4A); therefore, the channel system likely initiated while there was no positive relief over the salt diapir (Fig. 6B). Overlying this channel system, seismic reflections onlap horizon 2 and are truncated by horizon 3 (Fig. 3).

Horizon 3 defines a $\sim 2 \mathrm{~km}$ wide and straight, north-south-oriented erosional surface (Fig. 2). In the northeast of the study area, the erosional surface is truncated by the salt diapir, and includes an arcuate scour to the west of the diapir (Fig. 2). High-amplitude, discontinuous seismic reflections are confined by the erosional surface (see RMS-amplitude extraction between horizons 3 and 5; Fig. 4B), with a thin section of more continuous reflections outside of it (Fig. 3). We 
185 interpret that horizon 3 defines the base of another channel system. Horizons 4 and 5 define the 186 base and top, respectively, of a relatively narrow $(<1 \mathrm{~km}$ ) channel form (Figs. 2, 3). This channel

187 form is the last-active channel of the system. Overlying horizon 5 is a section of low-to-moderate 188 amplitude, chaotic seismic reflections that we interpret to be mass-transport deposits (Fig. 3). 189 These deposits are emplaced from northwest to southeast (Figs. 2, 3). The channel system appears 190 to shutdown with the emplacement of mass-transport deposits overlying horizon 5. Horizon 6 191 locally truncates horizons 3, 4, and 5 (Figs. 2, 3) and forms the base of a sequence of Pliocene192 Pleistocene channel and mass-transport deposits, which were studied by Ceyhan (2017). The 193 channel system between horizons 3 and 5 exhibits the characteristics of meander cutoff and 194 downstream translation in a topographic low adjacent to a salt diapir and is the main focus of this 195 study (Figs. 5, 6A). Below we will provide more detailed interpretations of the seismic196 stratigraphic architecture of this channel system.

197 A coherence attribute map between horizons 3 and 5 shows a pair of channel-bend cutoffs 198 in a syncline adjacent to the northeastern diapir (Fig. 5). These cutoffs are truncated by the last199 active channel defined by horizons 4 and 5, which exhibits a pair of $\sim 90^{\circ}$ bends as it crosses the 200 diapir (Fig. 5). This last-active channel is approximately straight as it descends to the south, where 201 it exhibits another pair of sharp bends. Upstream from these bends, low coherence values define 202 arcuate shapes, which are parallel to the concave (outer) bend of the last channel (Fig. 5). These 203 arcuate shapes are defined by north-to-south dipping, downstream-translating, high-amplitude 204 seismic reflections in cross section (Fig. 5b). This stratigraphic architecture suggests a channel 205 evolution beginning with the development of highly sinuous meanders in a syncline adjacent to 206 salt, followed by cutoff and the generation of a high-curvature perturbation, which resulted in 207 multiple bends that translated $\sim 10 \mathrm{~km}$ downstream from north to south. Remnant channel deposits 
208 with concave bends, parallel to the outer bend of the last channel, developed in the wake of this 209 downstream translation. We have two remaining questions. First, is this channel evolution 210 feasible? Our interpretation of the seismic-stratigraphic architecture and evolution of the channel

211 system between horizons 3 and 5 is a hypothesis to test with a simple forward model of 212 meandering-channel evolution (Sylvester and Covault, 2016). Second, if the seismic-stratigraphic 213 evolution is confirmed by numerical modeling, what is the underlying control on the sequence of 214 meander-loop expansion, cutoff, and downstream translation? Specifically, what is the role of 215 structural deformation in promoting these processes in tectonically active salt basins? Some of the 216 key channelized stratigraphic patterns in the study area are associated with the northeastern diapir; 217 to understand the growth of this diapir and the resultant topography, we apply a 2D structural 218 restoration to the cross-section profile A of Figure 3.

\section{Structural restoration}

Based on the observation that the channel system passed directly over the salt diapir (Fig.

222 4A), we conclude that the diapir had little or no positive relief between deposition of horizons 1 223 and 2 (Fig. 6B). Deposits between horizons 2 and 5, however, thin dramatically onto the diapir. 224 Furthermore, horizon 5 incises the diapir roof. These observations suggest that renewed uplift of 225 the diapir started after horizon 2. What could have caused this? We interpret a mild shortening 226 event beginning at horizon 2 time; the unit between horizons 1 and 2 is nearly isopachous on the 227 east side of the diapir, and it is then uplifted, onlapped, and truncated (see profile A of Fig. 3). 228 Uplift of an isopachous roof is a diagnostic feature of diapir shortening (e.g., Vendeville and 229 Nilsen, 1995). 
We constructed our section restoration using this contractional interpretation (Fig. 7). We

interpreted a slight topographic low above the diapir, possibly as a result of salt dissolution, prior

to the onset of shortening. This topographic low focused a channel system over the diapir crest (see 'horizon 2 - pre shortening' of Fig. 7). Mild shortening arched and uplifted the diapir crest. Uplift above and adjacent to the diapir created a syncline to the west of the diapir, at the intersection of the east-dipping regional slope and the west-dipping flank of the diapir uplift (see 'horizon 2 post shortening' of Fig. 7). The supradiapir channel system shifted to this syncline, where it cut the meander loops at horizon 3 (see 'horizon 3' structure map of Fig. 2). These meanders are at the base of the channel-bend cutoffs between horizons 3 and 5. Shortening continued to the present based on folding of younger units and erosion of the modern seafloor (Fig. 7). Total shortening in the restoration is only $85 \mathrm{~m}$; however, even this modest shortening was sufficient to change seafloor topography and shift channel-system location.

\section{Numerical model of channel evolution}

Most numerical models of meandering are initialized with a straight centerline that has random noise added throughout its entire length (e.g., Sun et al., 1996; Limaye and Lamb, 2013). Although both expansion and translation are common in these models, long stretches of deposits showing downstream translation are rarely preserved, as their upstream side gets rapidly eroded by the upstream meanders. The seismic-reflection data show highly sinuous channel cutoffs in a syncline adjacent to a salt diapir, which transition downstream to a straighter channel with a few bends downstream of the structure (Fig. 5). In general, for simple geometric reasons, cutoff events result in small but high-curvature bends (e.g., Camporeale et al., 2008). Therefore, we have used an initial condition with a single perturbation of relatively high curvature that affects an otherwise 
253 straight channel (Figs. 8, 9 and Supplementary Animations 1,2). It is tempting to think that for a 254 given channel size, the amount of translation and expansion would be the same. However, the 255 duration and length of translation are affected by channel depth $D$ and friction factor $C_{f}$ of the 256 exponent $\alpha$ (Eq. 4). In general, a smaller value of $\alpha$ results in longer downstream translation (Fig. 2578 and Supplementary Animation 1). To generate translation similar to that observed in the Campos 258 basin example, we applied a relatively small width-to-depth ratio and a small friction factor. We 259 found that values of $W=300 \mathrm{~m}, D=30 \mathrm{~m}$, and $C_{f}=0.01275$ result in a reasonable match to the 260 channel system in the Campos basin (Fig. 9 and Supplementary Animation 2). These depth and 261 width values are likely to be representative of the lower, higher density part of the channel262 sculpting sediment-gravity flows, which probably drive the evolution of the plan-view pattern and 263 the width-to-wavelength scaling (cf. Pirmez and Imran, 2003). Of course, larger values of $D$ give 264 the same result if $C_{f}$ is increased by the same amount. The initial bend migrates downstream, 265 leaving behind deposits; at the same time, two or three additional bends develop further 266 downstream, in a wave-like fashion (Fig. 9 and Supplementary Animation 2). These bends are 267 strongly translational in nature and leave behind significant translation-related deposits similar in 268 scale to the channel deposits in the Campos basin. However, the preservation potential of these 269 deposits is variable: as bends gradually switch from translation to expansion, the translation-related 270 units of the downstream bends tend to be eroded, and only the downstream migration of the first 271 couple of bends is preserved (e.g., see model with $\alpha=0.0015$ of Fig. 8 and Supplementary 272 Animation 1). The Campos basin example we have described here is likely a relatively short-lived 273 feature that has developed from a low-sinuosity, newly established channel with a single 274 perturbation and was abandoned before meander expansion took over from translation. Indeed, the 
275 channel system is shutdown following the emplacement of the mass-transport complex above 276 horizon 5.

\section{DISCUSSION} basin: upstream meander cutoffs result in a high-curvature perturbation that initiates additional bends downstream, and all bends leave downstream-translating channel deposits in their wake

282 (Figs. 5, 9). The geomorphologic and stratigraphic expression of these deposits is reminiscent of 283 fluvial counter-point bars (Fig. 9C). Counter-point bars form where long-term deposition takes 284 place on a concave bank; the corresponding deposits are usually finer grained than those of the 285 point bar (Smith et al., 2009). Qualitatively, counter-point bars have been linked to downstream 286 translation and confinement; although there is evidence that confinement is not always necessary. 287 Sharp and small cutoff-related bends in rivers often result in significant translation and are likely locations of counter-point bar formation (Fig. 9C).

Our integrated seismic-stratigraphic interpretation and numerical modeling suggests that 290 translation might be common in settings that promote (1) meander cutoffs and the generation of 291 high-curvature bends, and (2) repeated local re-establishment of relatively straight channels. The 292 former can happen in salt-tectonic provinces, in which deformation can draw channel pathways 293 into low topography (e.g., Gee and Gawthorpe, 2006; Oluboyo et al., 2014). The latter can happen 294 when a large mass-transport event erases the existing channel topography, either through erosion 295 or burial, and sets the stage for a new channel with low sinuosity. These conditions are satisfied 296 by continental margins affected by salt tectonics, such as the area of this study in the Campos 297 basin. Here, a syncline adjacent to a salt diapir appears to have localized sinuous meander loops, 
which were cut off as they expanded into the syncline. Other examples of downstream translation of submarine-channel bends have been linked to major changes in flow regime and type of sediment load. However, we propose that allogenic changes in sediment delivery to the system are not necessary to produce these deposits and downstream translation might be common in rapidly deforming settings, like salt basins, that promote localized subsidence, meander cutoffs, and rapidly translating, high-curvature bends.

With respect to the architecture of continental margins, submarine-channel systems commonly include a complex stacking of erosional remnants of sandstone-dominated channel fills (Deptuck et al., 2003; 2007; Hodgson et al., 2011; McHargue et al., 2011; Sylvester et al., 2011), especially during their early evolution when cutoffs are more common (Sylvester and Covault, 2016). This architecture is reminiscent of the sheet-like sand bodies produced by the combined translation and expansion of rivers, although aggradation is often significantly higher in submarine channels (Jobe et al., 2016). Further work is needed to evaluate whether (1) downstream translation is more common in submarine channels than in rivers and (2) submarine "counter-point bars" are

312 relatively fine-grained, like in rivers (Smith et al. 2009). Our results and observations suggest that 313 long-term and long-distance translation is an important component of submarine-channel 314 evolution, and, similar to rivers, it is primarily driven by the downstream shift of the location of 315 maximum migration relative to the bend apex (Furbish, 1988; Sylvester et al., in revision). This 316 phase lag is well known from meandering models (e.g., Seminara, 2006) and is the result of the 317 influence of upstream curvatures on the local migration rate. This influence and the resulting translation are stronger when the channel is deep and friction factor is low (e.g., a smaller value of $\alpha$, Fig. 8 and Supplementary Animation 1); therefore, a possible explanation for the excessive translation observed in the Campos basin and elsewhere is that submarine channels tend to be 
321 overall deeper and, perhaps due to the lack of large mid-channel bars and bedforms, smoother than

322 their fluvial counterparts.

\section{CONCLUSIONS}

325 We characterized the structural and seismic-stratigraphic evolution of a Miocene salt diapir 326 and submarine-channel system in the tectonically active Campos salt basin. Structural restoration 327 shows diapir shortening created a syncline to the west of the diapir, which localized a channel328 system depocenter comprising meander cutoffs (Fig. 7). We used a simple forward model of 329 meandering-channel evolution to show that these upstream meander cutoffs resulted in a high330 curvature perturbation that initiated additional bends downstream, and all bends left downstream331 translating channel deposits in their wake (Fig. 9 and Supplementary Animation 2). These deposits 332 are reminiscent of fluvial counter-point bars, which might commonly develop during the early 333 evolution of relatively deep, smooth-floored submarine-channel systems, and, in general, after the 334 formation of high-curvature perturbations. Moreover, we show that downstream translation can 335 develop without allogenic changes in sediment delivery to the system and without any 336 confinement. Early work on submarine-channel evolution has suggested that downstream 337 translation is rare; we suspect it to be a common migration process in submarine-channel systems 338 in salt basins and other tectonically active settings with complex topography, which might promote 339 the development of cutoffs and other perturbations. 


\section{ACKNOWLEDGMENTS}

342 We thank Investigação Petrolífera Limitada (PGS) for the donation of seismic-reflection data. We 343 are grateful to Emerson for the donation of Paradigm SeisEarth $®$ interpretation and visualization 344 software. We thank the sponsors of the Quantitative Clastics Laboratory 345 (http://www.beg.utexas.edu/qcl) and the Applied Geodynamics Laboratory 346 (http://www.beg.utexas.edu/agl). We acknowledge former AGL researcher Dan Carruthers for 347 initiating chronostratigraphic analysis of the data in the Campos basin. We thank Oliver Duffy and 348 Naiara Fernandez for early assistance with the structural deformation of the Campos basin. We are 349 grateful to Paul Durkin and David Mohrig for discussions about channel-bend translation and 350 counter-point bars.

\section{REFERENCES CITED}

353 Bahorich, M. S., and Farmer, S. L., 1995, 3-D seismic discontinuity for faults and stratigraphic 354 features; The coherence cube: SEG Technical Program Expanded Abstracts 1995, Society of Exploration Geophysicists, p. 93-96.

Barnes, N. E., and Normark, W. R., 1985, Diagnostic parameters for comparing modern submarine fans and ancient turbidite systems, in Bouma, A. H., Normark, W. R., and Barnes, N. E., eds., Submarine fans and related turbidite systems: Springer, New York, NY, p. 13-14.

Bruhn, C. H. L., 1998, Major types of deep-water reservoirs from the eastern Brazilian rift and passive margin basins: AAPG International Conference \& Exhibition, Rio de Janeiro, Brazil, AAPG Search and Discovery Article \#90933. 
Bruhn, C. H., Gomes, J. A. T., Del Lucchese Jr, C., and Johann, P. R., 2003, Campos basin; Reservoir characterization and management-Historical overview and future challenges: Offshore Technology Conference, Houston, Texas, OTC-15220-MS.

Camporeale, C., Perucca, E., and Ridolfi, L., 2008, Significance of cutoff in meandering river dynamics: Journal of Geophysical Research Earth Surface, 113(F1).

Carminatti, M., and Scarton, J. C., 1991, Sequence stratigraphy of the Oligocene turbidite complex of the Campos Basin, offshore Brazil; an overview: in Weimer, P., and Link, M. H., eds., Seismic facies and sedimentary processes of submarine fans and turbidite systems: Springer, New York, NY, 241-246.

Ceyhan, C., 2017, Interplay of salt-influenced structural deformation and submarine channel evolution in the Campos Basin, offshore Brazil [M. S. thesis]: the University of Texas at Austin, $80 \mathrm{p}$.

Chang, H. K., Kowsmann, R. O., Figueiredo, A. M. F., and Bender, A., 1992, Tectonics and stratigraphy of the East Brazil Rift system; an overview: Tectonophysics, v. 213, p. 97138.

Contreras, J., 2011, Seismo-stratigraphy and numerical basin modeling of the southern Brazilian continental margin (Campos, Santos, and Pelotas basins) [Ph. D. thesis]: Ruprecht-KarlsUniversität, Heidelberg, Germany, 146 p.

Contreras, J., Zühlke, R., Bowman, S., and Bechstädt, T., 2010, Seismic stratigraphy and subsidence analysis of the southern Brazilian margin (Campos, Santos and Pelotas basins): Marine and Petroleum Geology, v. 27, p. 1952-1980.

Damuth, J. E., Kolla, V., Flood, R. D., Kowsmann, R. O., Monteiro, M. C., Gorini, M. A., Palma, J. J. C., and Belderson, R. H., 1983, Distributary channel meandering and bifurcation 
patterns on the Amazon deep-sea fan as revealed by long-range side-scan sonar (GLORIA): Geology, v. 11, p. 94-98.

De Gasperi, A., and Catuneanu, O., 2014, Sequence stratigraphy of the Eocene turbidite reservoirs in Albacora field, Campos Basin, offshore Brazil: AAPG bulletin, v. 98, p. 279-313.

Demercian, S., Szatmari, P., and Cobbold, P. R., 1993, Style and pattern of salt diapirs due to thinskinned gravitational gliding, Campos and Santos basins, offshore Brazil: Tectonophysics, v. 228 , p. 393-433.

Deptuck, M. E., Steffens, G. S., Barton, M., and Pirmez, C., 2003, Architecture and evolution of upper fan channel-belts on the Niger Delta slope and in the Arabian Sea: Marine and Petroleum Geology, v. 20, p. 649-676.

Deptuck, M. E., Sylvester, Z., Pirmez, C., and O’Byrne, C., 2007, Migration-aggradation history and 3-D seismic geomorphology of submarine channels in the Pleistocene Benin-major Canyon, western Niger Delta slope: Marine and Petroleum Geology, v. 24, p. 406-433.

De Ruig, M. J., and Hubbard, S. M., 2006, Seismic facies and reservoir characteristics of a deepmarine channel belt in the Molasse foreland basin, Puchkirchen Formation, Austria: AAPG bulletin, v. 90, p. 735-752.

Fetter, M., 2009, The role of basement tectonic reactivation on the structural evolution of Campos Basin, offshore Brazil; Evidence from 3D seismic analysis and section restoration: Marine and Petroleum Geology, v. 26, p. 873-886.

Finnegan, N. J., and Dietrich, W. E., 2011, Episodic bedrock strath terrace formation due to meander migration and cutoff: Geology, v. 39, p. 143-146.

Furbish, D. J., 1988, River-bend curvature and migration; How are they related?: Geology, v. 16, p. $752-755$. 
Galy, V., Beyssac, O., France-Lanord, C., and Eglinton, T., 2008, Recycling of graphite during Himalayan erosion; a geological stabilization of carbon in the crust: Science, v. 322, p. 943-945.

Gee, M. J. R., and Gawthorpe, R. L., 2006, Submarine channels controlled by salt tectonics; Examples from 3D seismic data offshore Angola: Marine and Petroleum Geology, v. 23, p. $443-458$.

Ghinassi, M., Ielpi, A., Aldinucci, M., and Fustic, M., 2016, Downstream-migrating fluvial point bars in the rock record: Sedimentary Geology, v. 334, p. 66-96.

Gorelick, N., Hancher, M., Dixon, M., Ilyushchenko, S., Thau, D., and Moore, R., 2017, Google Earth Engine; Planetary-scale geospatial analysis for everyone: Remote Sensing of Environment, v. 202, p. 18-27.

Guardado, L. R., Gamboa, L. A. P., and Lucchesi, C. F., 1990, Petroleum geology of the Campos Basin, Brazil, a model for a producing Atlantic type basin: AAPG memoir, v. 48, p. 3-36.

Guardado, L. R., Spadini, A. R., Brandão, J. S. L., and Mello, M. R., 2000, Petroleum system of the Campos Basin, Brazil: AAPG memoir, v. 73, p. 317-324.

Hickin, E. J., and Nanson, G. C., 1975, The character of channel migration on the Beatton River, northeast British Columbia, Canada: Geological Society of America Bulletin, v. 86, p. 487494.

Hodgson, D. M., Di Celma, C. N., Brunt, R. L., and Flint, S. S., 2011, Submarine slope degradation and aggradation and the stratigraphic evolution of channel-levee systems: Journal of the Geological Society, v. 168, p. 625-628.

Howard, A. D., and Knutson, T. R., 1984, Sufficient conditions for river meandering; A simulation approach: Water Resources Research, v. 20, p. 1659-1667. 
Hubbard, S. M., Covault, J. A., Fildani, A., and Romans, B. W., 2014, Sediment transfer and deposition in slope channels; Deciphering the record of enigmatic deep-sea processes from outcrop: Geological Society of America Bulletin, v. 126, p. 857-871.

Hudec, M. R., and Jackson, M. P., 2007, Terra infirma; Understanding salt tectonics: EarthScience Reviews, v. 82, p. 1-28.

Ikeda, S., Parker, G., and Sawai, K., 1981, Bend theory of river meanders. Part 1. Linear development: Journal of Fluid Mechanics, v. 112, p. 363-377.

Janocko, M., Nemec, W., Henriksen, S., and Warchoł, M., 2013, The diversity of deep-water sinuous channel belts and slope valley-fill complexes: Marine and Petroleum Geology, v. 41, p. 7-34.

Jobe, Z. R., Howes, N. C., and Auchter, N. C., 2016, Comparing submarine and fluvial channel kinematics: Implications for stratigraphic architecture: Geology, v. 44, p. 931-934.

Kolla, V., Bandyopadhyay, A., Gupta, P., Mukherjee, B., and Ramana, D. V., 2012, Morphology and internal structure of a recent upper Bengal fan-valley complex, in Prather, B. E., Deptuck, M. E., Mohrig, D., von Hoorn, B., and Wynn, R. B., Application of the Principles of Seismic Geomorphology to Continental-Slope and Base-of-Slope Systems; Case Studies from Seafloor and Near-Seafloor Analogues: SEPM Special Publication, v. 99, p. 347-369.

Limaye, A. B., and Lamb, M. P., 2014, Numerical simulations of bedrock valley evolution by meandering rivers with variable bank material: Journal of Geophysical Research Earth Surface, v. 119, p. 927-950.

Madof, A. S., Christie-Blick, N., and Anders, M. H., 2009, Stratigraphic controls on a saltwithdrawal intraslope minibasin, north-central Green Canyon, Gulf of Mexico; Implications for misinterpreting sea level change: AAPG bulletin, v. 93, p. 535-561. 
McHargue, T., Pyrcz, M. J., Sullivan, M. D., Clark, J. D., Fildani, A., Romans, B. W., Covault, J. A., Levy, M., Posamentier, H. W., and Drinkwater, N. J., 2011, Architecture of turbidite channel systems on the continental slope; Patterns and predictions: Marine and Petroleum Geology, v. 28, p. 728-743.

Mendoza-Veloza, R., 2007, The architecture of lower-slope channel complexes, offshore Gabon, West Africa [M. S. thesis]: the University of Texas at Austin, 110 p.

Mohriak, W. U., Mello, M. R., Dewey, J. F., and Maxwell, J. R., 1990, Petroleum geology of the Campos Basin, offshore Brazil: Geological Society, London, Special Publications, v. 50, p. 119-141.

Mohriak, W. U., Szatmari, P., and Anjos, S., 2012, Salt; Geology and tectonics of selected Brazilian basins in their global context: Geological Society, London, Special Publications, v. 363 , p. $131-158$.

Oluboyo, A. P., Gawthorpe, R. L., Bakke, K., and Hadler-Jacobsen, F., 2014, Salt tectonic controls on deep-water turbidite depositional systems; Miocene, southwestern Lower Congo Basin, offshore Angola: Basin Research, v. 26, p. 597-620.

Peakall, J., McCaffrey, B., and Kneller, B., 2000, A process model for the evolution, morphology, and architecture of sinuous submarine channels: Journal of Sedimentary Research, v. 70, p. $434-448$.

Peres, W. E., 1993, Shelf-fed turbidite system model and its application to the Oligocene deposits of the Campos Basin, Brazil: AAPG bulletin, v. 77, p. 81-101.

Pettingill, H. S., and Weimer, P., 2002, Worldwide deepwater exploration and production; Past, present, and future: The Leading Edge, v. 21, p. 371-376. 
Piper, D. J., and Normark, W. R., 2001, Sandy fans-from Amazon to Hueneme and beyond: AAPG bulletin, v. 85, p. 1407-1438.

Pirmez, C., and Imran, J., 2003, Reconstruction of turbidity currents in Amazon Channel: Marine and Petroleum Geology, v. 20, p. 823-849.

Posamentier, H. W., 2003, Depositional elements associated with a basin floor channel-levee system: case study from the Gulf of Mexico: Marine and Petroleum Geology, v. 20, p. 677690.

Posamentier, H. W., and Kolla, V., 2003, Seismic geomorphology and stratigraphy of depositional elements in deep-water settings: Journal of Sedimentary Research, v. 73, p. 367-388.

Romans, B. W., Castelltort, S., Covault, J. A., Fildani, A., and Walsh, J. P., 2016, Environmental signal propagation in sedimentary systems across timescales: Earth-Science Reviews, v. 153, p. 7-29.

Seminara, G., 2006, Meanders: Journal of Fluid Mechanics, v. 554, p. 271-297.

Smith, D. G., Hubbard, S. M., Leckie, D. A., and Fustic, M., 2009, Counter point bar deposits; Lithofacies and reservoir significance in the meandering modern Peace River and ancient McMurray Formation, Alberta, Canada: Sedimentology, v. 56, p. 1655-1669.

Sun, T., Meakin, P., Jøssang, T., and Schwarz, K., 1996, A simulation model for meandering rivers: Water Resources Research, v. 32, p. 2937-2954.

Sylvester, Z., and Covault, J. A., 2016, Development of cutoff-related knickpoints during early evolution of submarine channels: Geology, v. 44, p. 835-838.

Sylvester, Z., Covault, J., and Durkin, P., in revision, High curvatures drive river meandering: Geology. 
Sylvester, Z., Pirmez, C., and Cantelli, A., 2011, A model of submarine channel-levee evolution based on channel trajectories; Implications for stratigraphic architecture: Marine and Petroleum Geology, v. 28, p. 716-727.

Vendeville, B. C., and Nilsen, K. T., 1995, Episodic growth of salt diapirs driven by horizontal shortening: SEPM Gulf Coast Section 16th Annual Research Foundation Conference, v. 285, p. 295.

Winter, W. R., Jahnert, R. J., and França, A. B., 2007, Bacia de campos: Boletim de Geociencias da Petrobras, v. 15, p. 511-529.

Wynn, R. B., Cronin, B. T., and Peakall, J., 2007, Sinuous deep-water channels; Genesis, geometry and architecture: Marine and Petroleum Geology, v. 24, p. 341-387.

\section{FIGURE CAPTIONS}

Figure 1. (A) Study area in the deep-water Campos basin. Gray polygon indicates location of seismic-reflection volume in B. Modified from Peres (1993). (B) Seafloor of the study area. Black dashed rectangle indicates location of maps in Figure 2.

Figure 2. (Above) Structure maps of horizons 1-6. Horizontal white lines in horizon 2 map indicate locations of west-east profiles in Figure 3. (Below) Isochore maps between horizons.

Figure 3. West-east seismic-reflection profiles (left) and interpreted depositional elements (right). Profiles are oriented west (left) to east (right). Profile locations are in Figure 2. Black dashed rectangles in seismic-reflection profiles (left) indicate locations of interpreted depositional elements (right).

Figure 4. RMS-amplitude maps between horizons 1-2 (A) and horizons 3-5 (B). 
Figure 5. Detailed seismic-stratigraphic interpretation of channel system between horizons 3-5. (Above) Uninterpreted (left) and interpreted (right) coherence maps. Solid black lines in interpreted (right) coherence map indicate locations of seismic-reflection profiles below. (Below) Interpreted seismic-reflection profile b-b' shows a depositional-dip view of northto-south dipping, downstream-translating, high-amplitude seismic reflections. Profile c-c' shows a depositional-strike view of the channel system.

Figure 6. Schematic submarine-channel orientation pre (below) and post (above) diapir shortening. Compare to Figure 4 RMS-amplitude maps.

Figure 7. Structural restoration. Early is at the bottom; present configuration is at the top. See text for explanation.

Figure 8. Forward models of channel evolution based on different values of $\alpha$ (Eq. 4). From bottom to top, decreasing $\alpha$ (increasing $D$, decreasing $C_{f}$ ) results in progressively larger meander size and more translation of a high-curvature perturbation. See Supplementary Animation 1.

Figure 9. Comparison of forward model (A) to channel system between horizons 3-5 in the Campos basin (B). Bends 1, 2, and 3 are comparable in parts A, B, and C. See Supplementary Animation 2 for evolution of part A and Figure 5 for detailed geomorphologic and stratigraphic character of the channel system in part B. (C) Plan-view patterns in parts A and B are similar to observations of the Rio Mamoré from Google Earth Engine (Gorelick et al., 2017). 

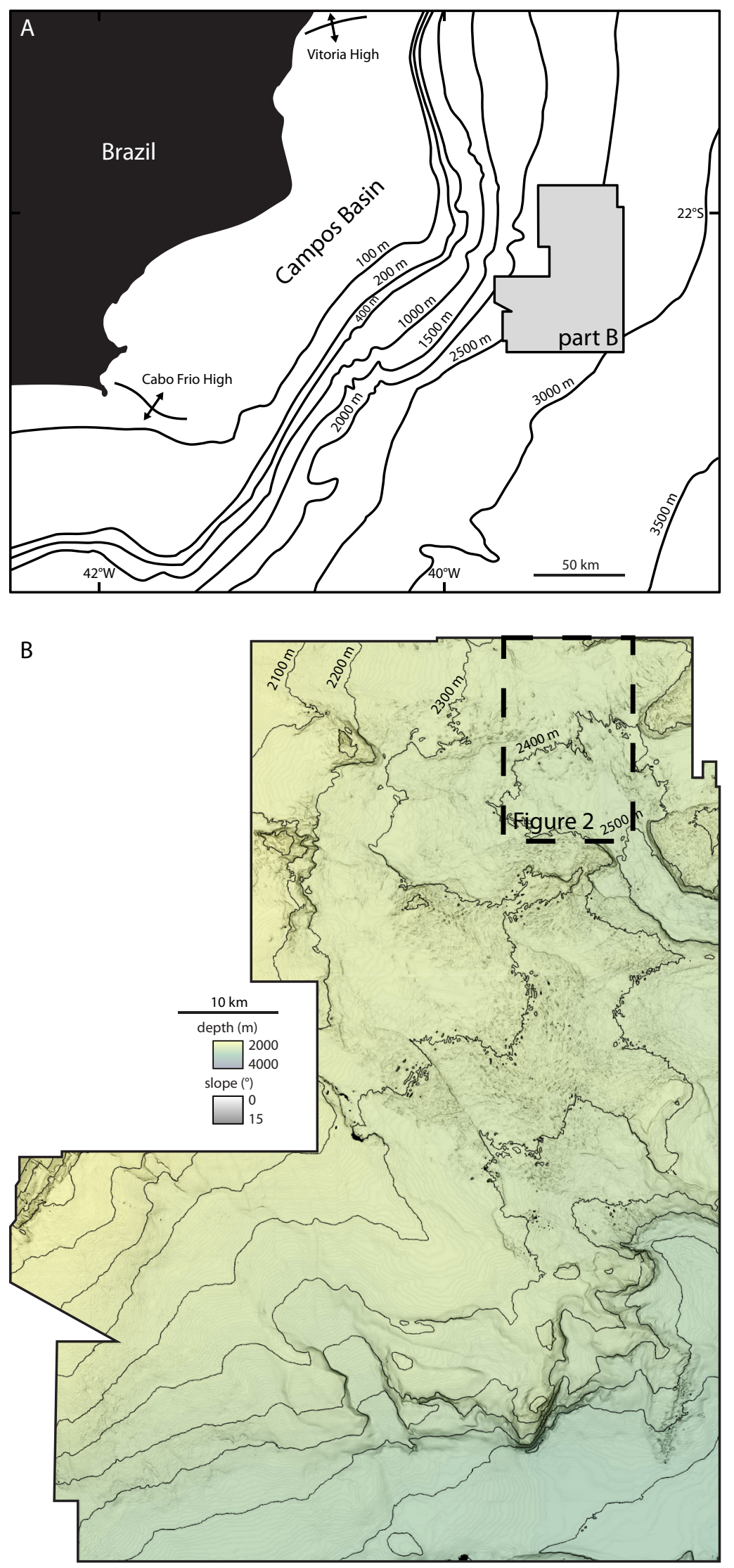

Figure 1. 

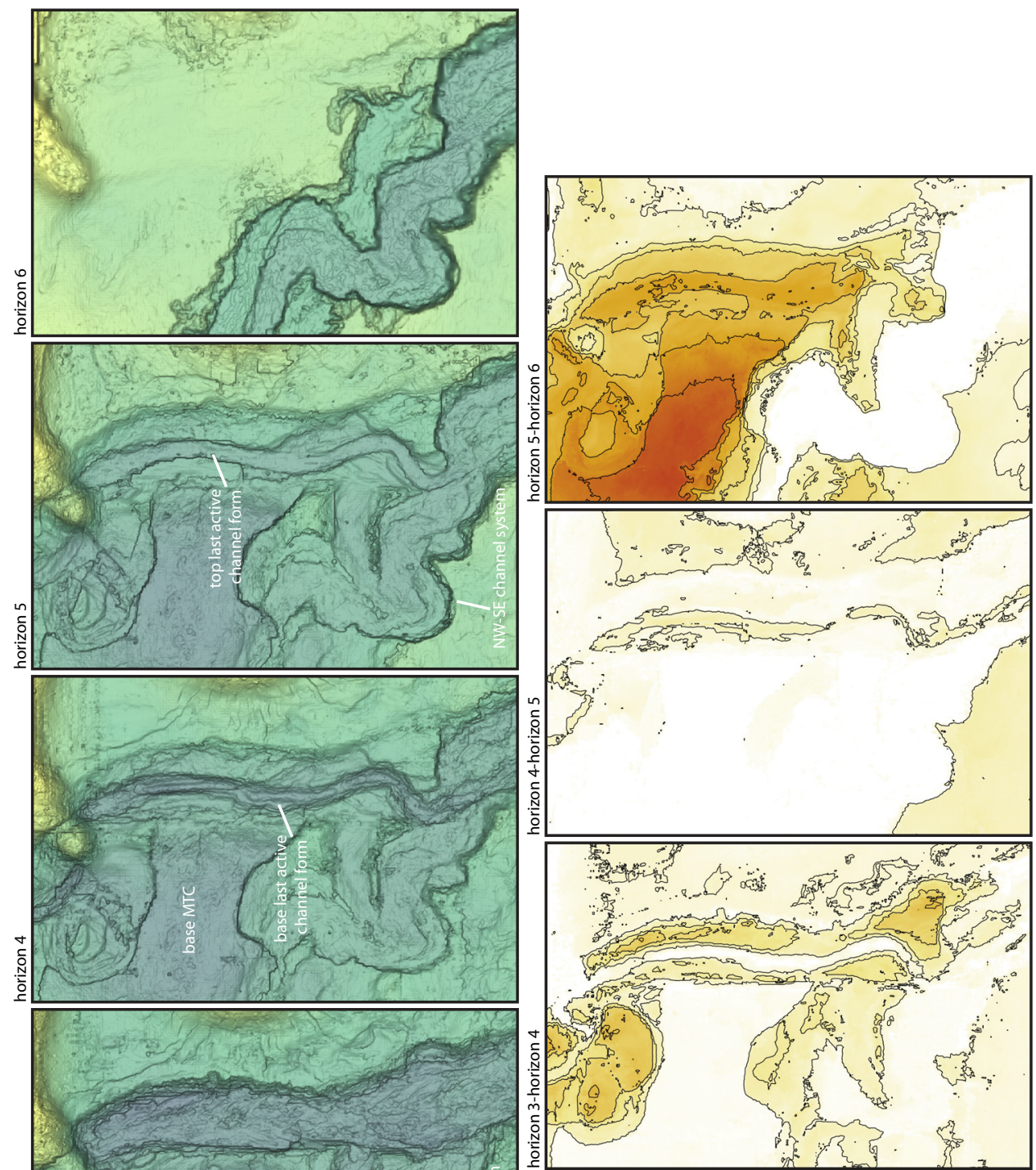

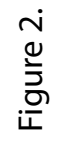
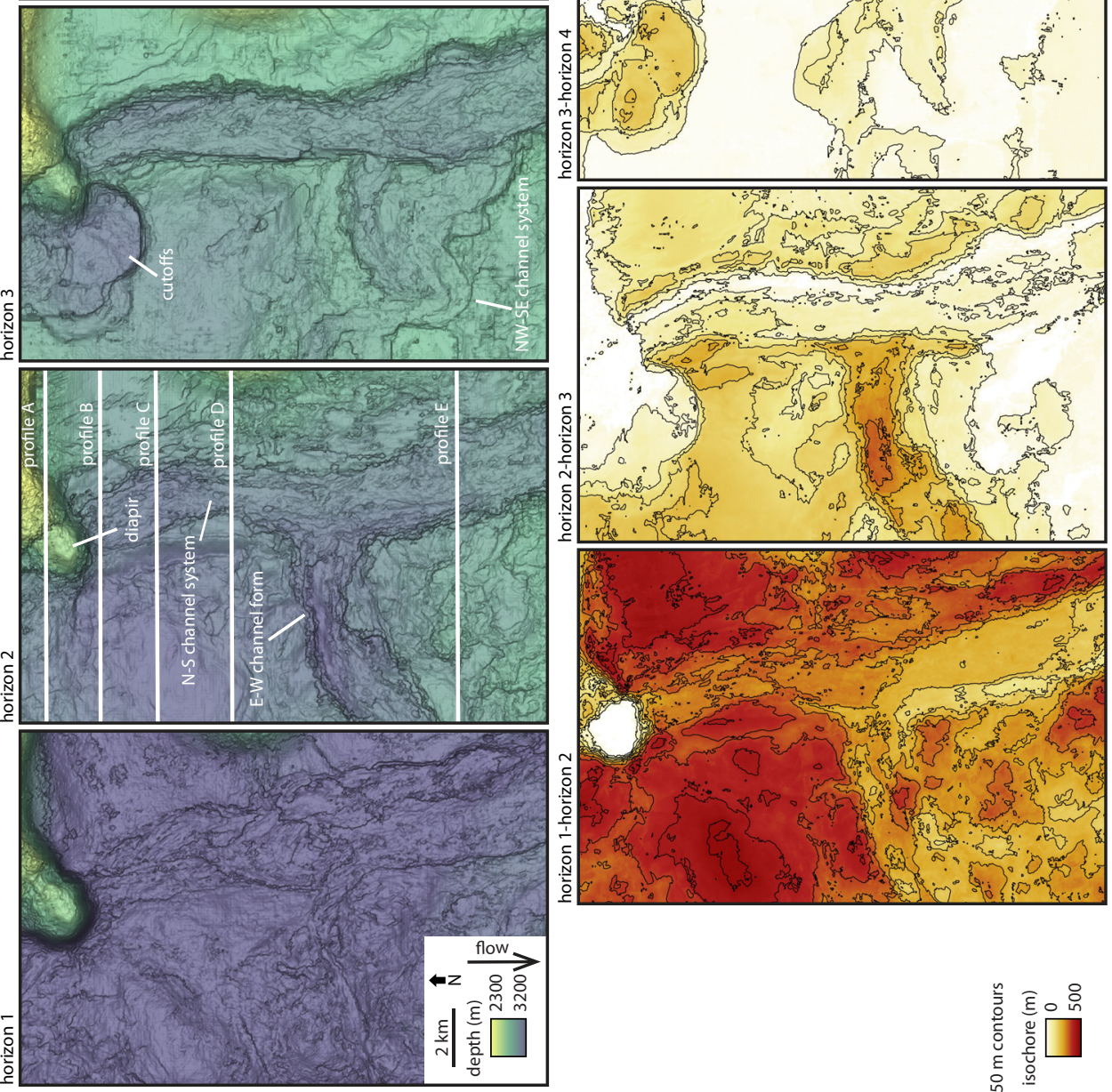


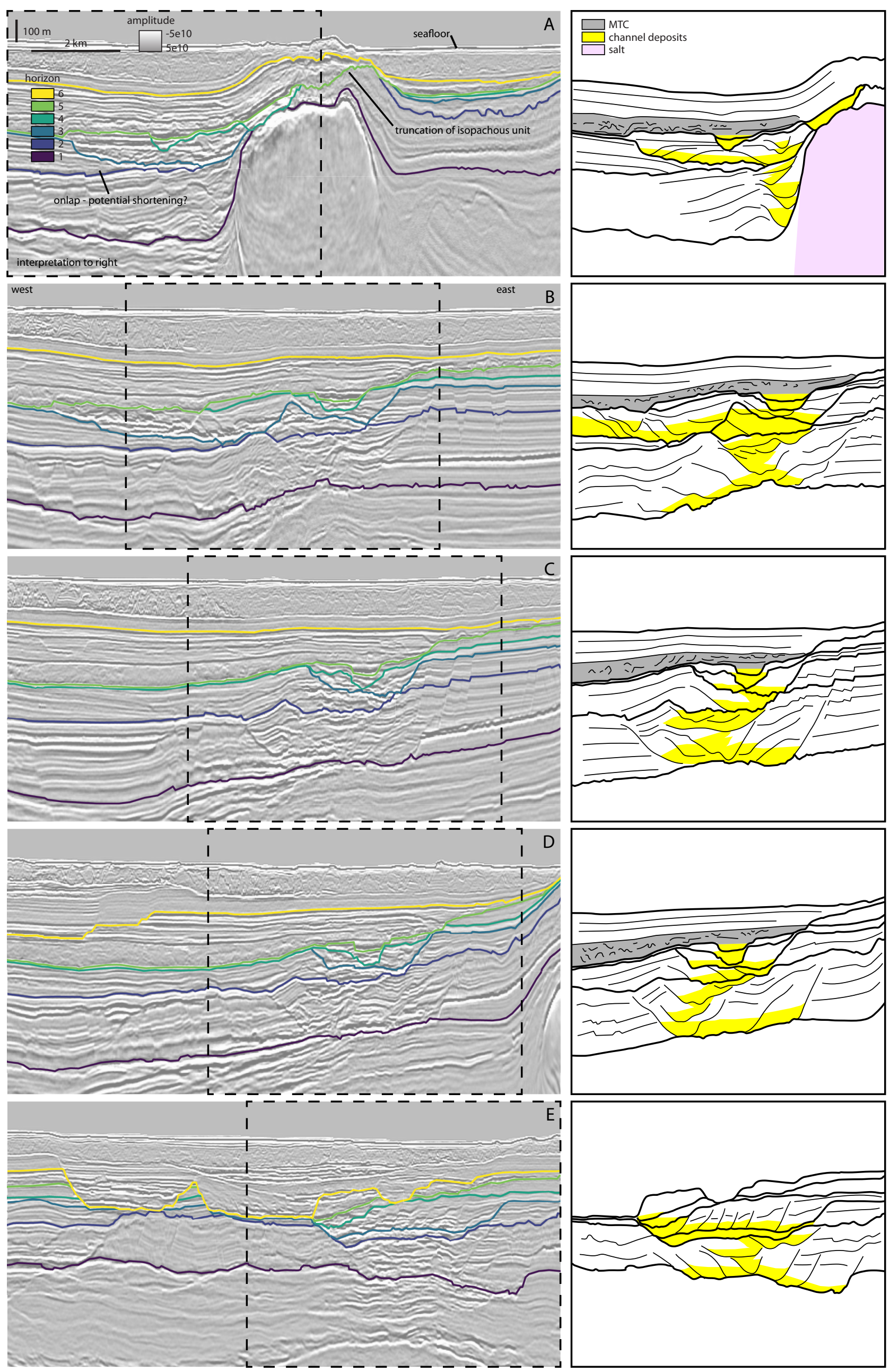

Figure 3 


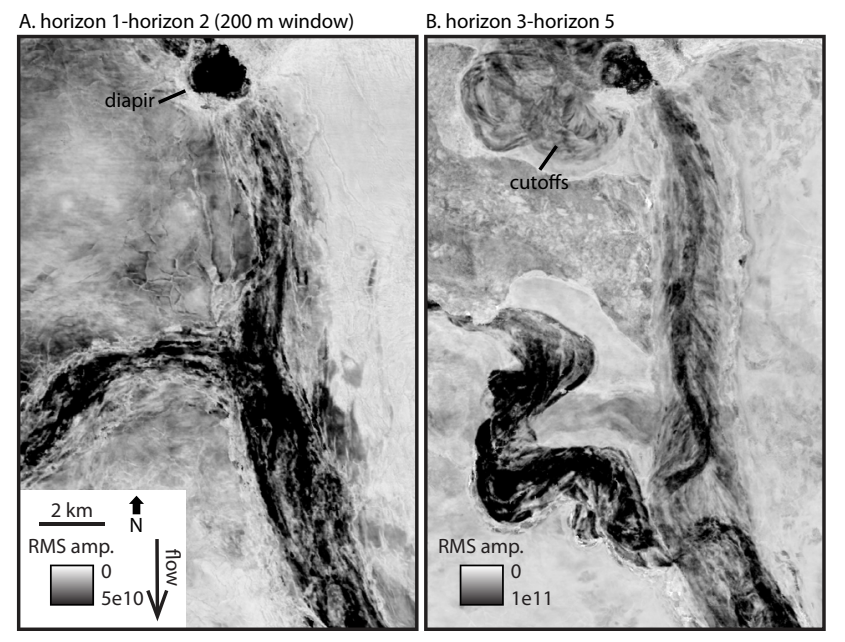

Figure 4. 

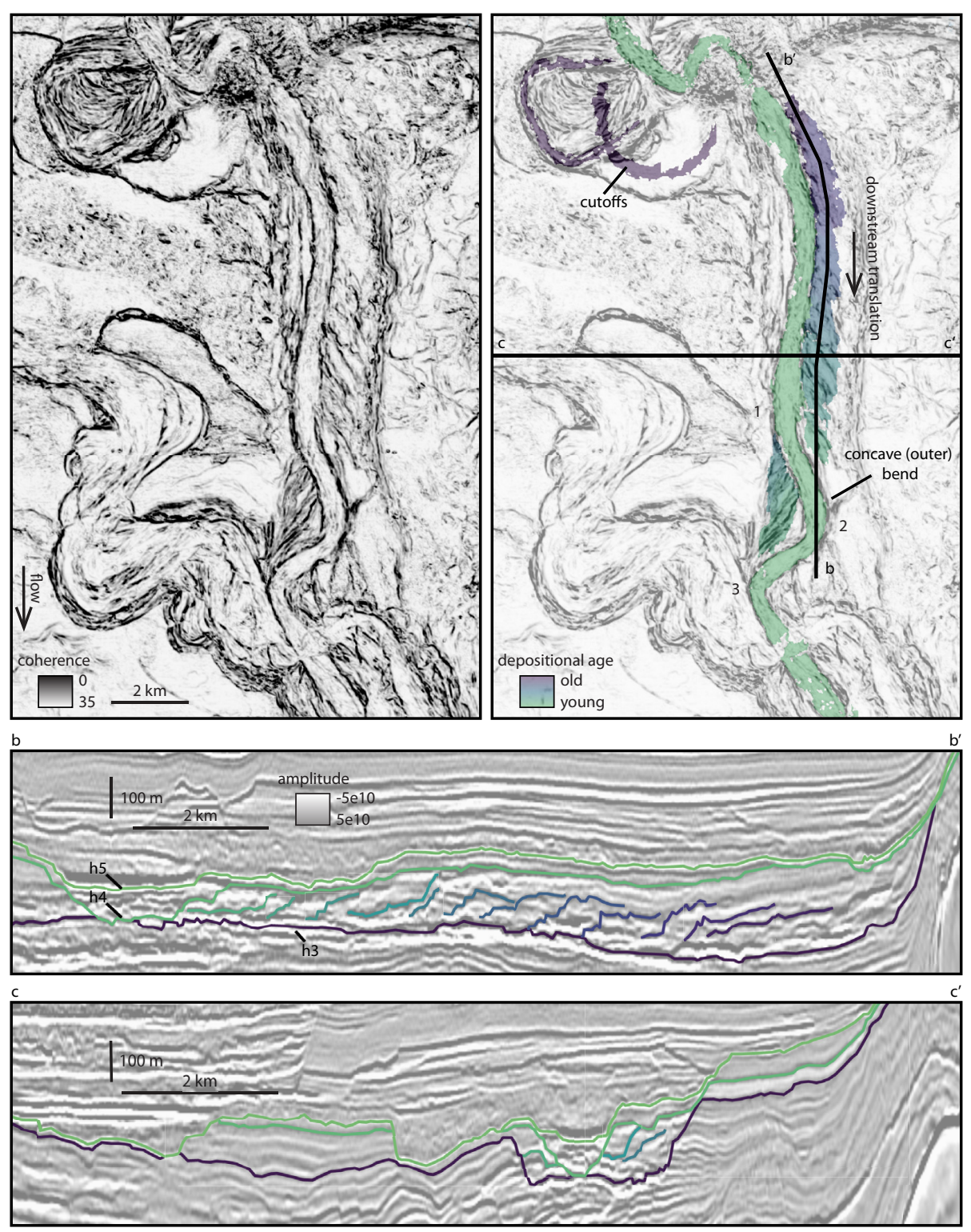

Figure 5. 
A. schematic horizon 4-5 post shortening channel system

accommodation from tilting \&

relative diapir inflation

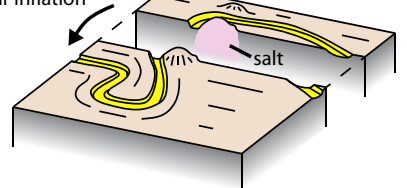

B. schematic horizon 1-2 pre shortening channel system

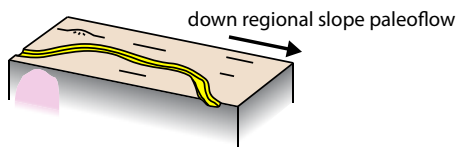

Figure 6. 


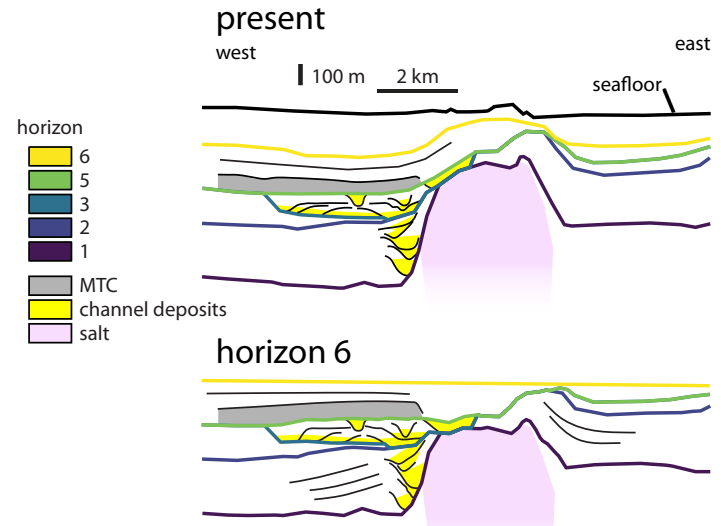

horizon 5

accommodation from tilting \& continued relative salt inflation

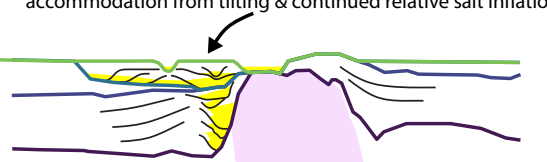

horizon 2 - post shortening

accommodation from tilting \& continued relative salt inflation

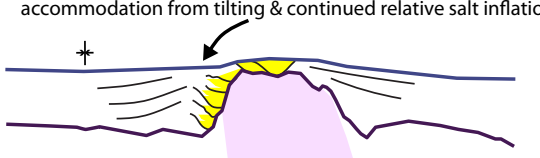

horizon 2 - pre shortening

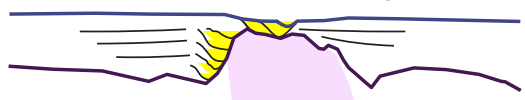

Figure 7. 


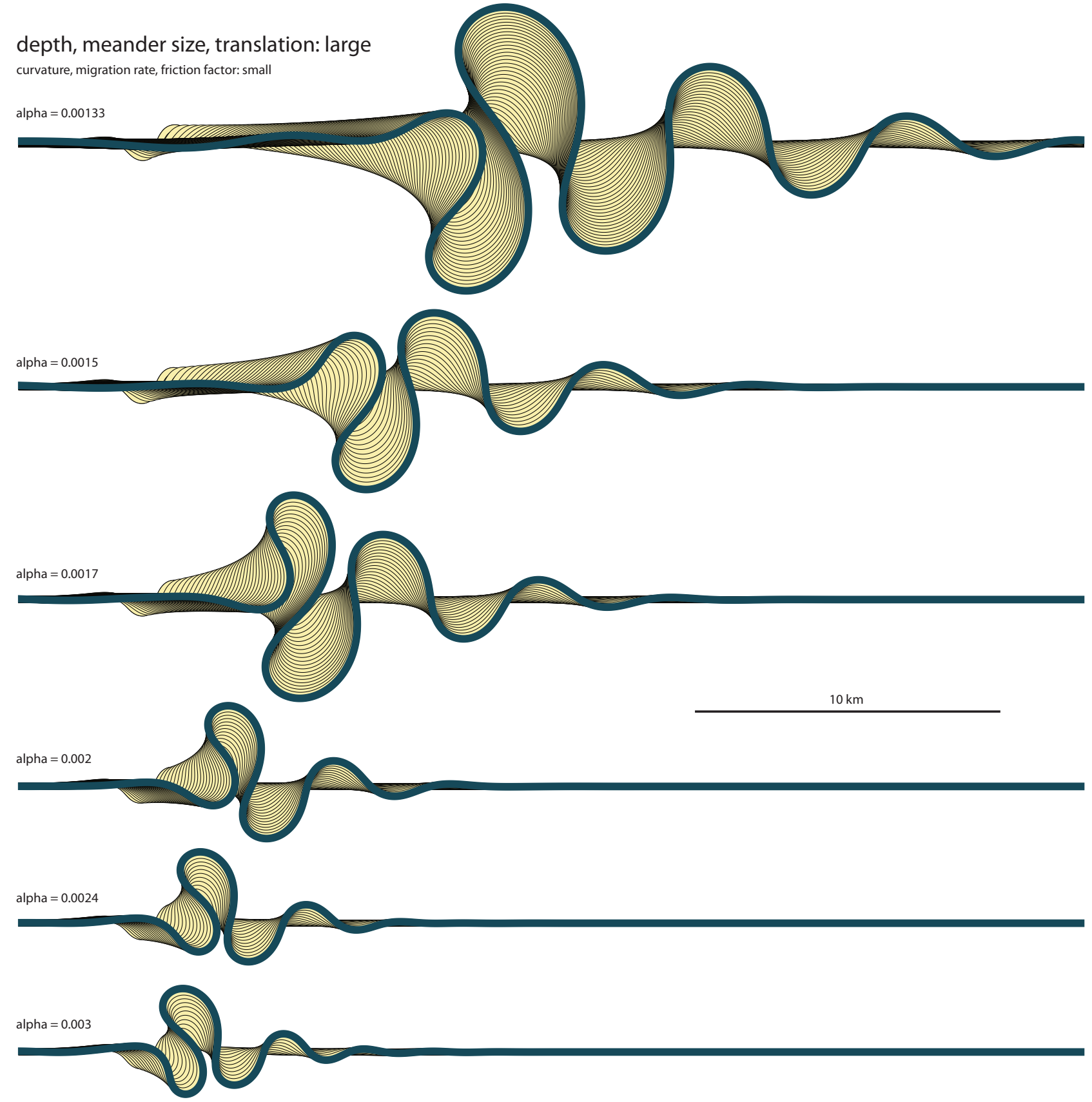

depth, meander size, translation: small

curvature, migration rate, friction factor: large

Figure 8 


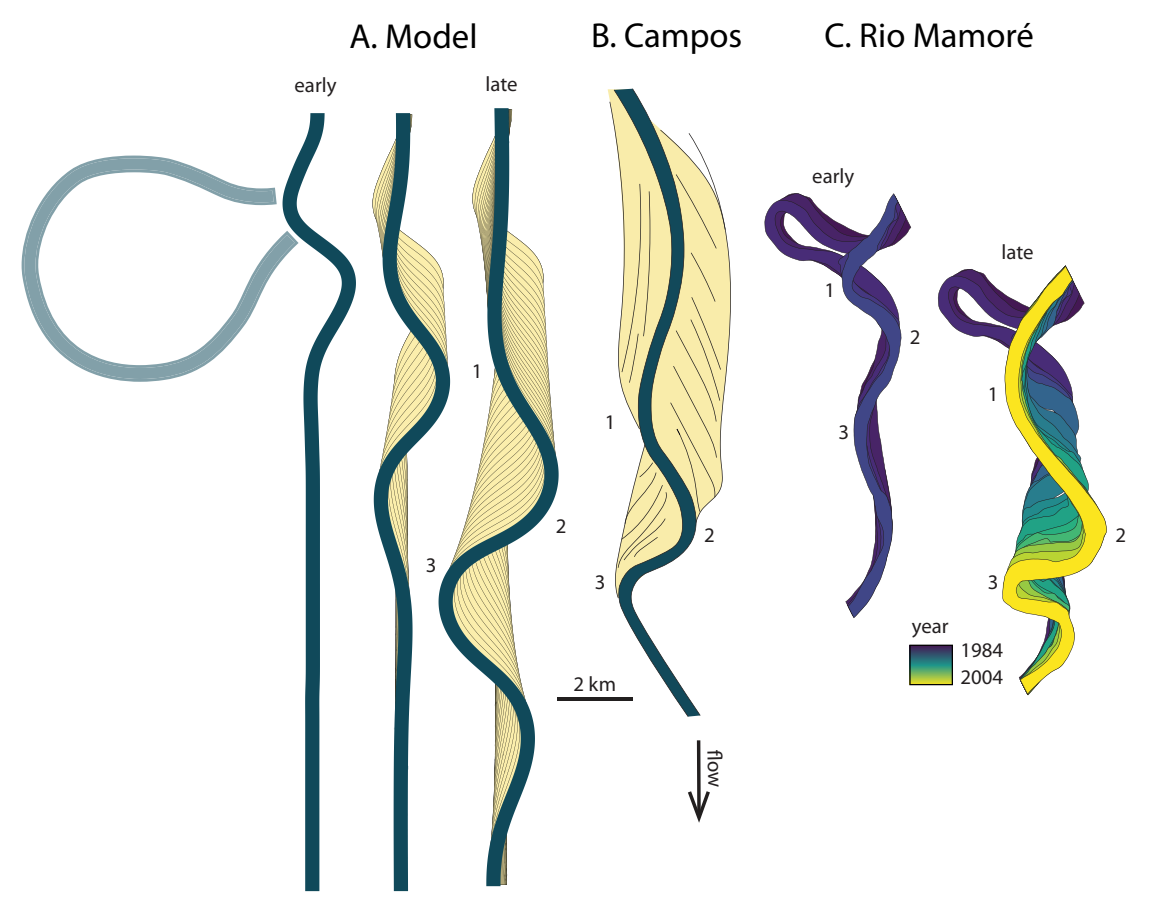

Figure 9. 